\title{
Feminist Interpretations of Witches and the Witch Craze in Contemporary Art by Women
}

\author{
Katy Deepwell ${ }^{1}$ \\ Middlesex University \\ The Burroughs, Hendon \\ London NW4 4BT \\ k.deepwell@mdx.ac.uk
}

\begin{abstract}
This article considers feminist interpretations of the witch in contemporary art in relation to the witch craze: examples are by Georgia Horgan, Ann-Sofi Sidén, Mathilde ter Heijne, Monica Sjöö, Tania Antoshina, Helen Chadwick, Jesse Jones, and Carolee Schneemann. The argument explores the ways that the figure of the witch is analyzed in three different feminist critiques of patriarchy, and subsequently pursues how these ideas have been taken up in contemporary art by these women artists. The differences between three authors: Matilda Joslyn Gage (1893); Mary Daly (1984); and Silvia Federici (2004) are highlighted and contrasted to other historians' analyses from the last thirty years of the fate of women accused as witches during the European Witch Hunt between the fifteenth to eighteenth centuries. This was a paper given at Misogyny: Witches and Wicked Bodies, Institute of Contemporary Arts, (ICA) London in March 2015.
\end{abstract}

Keywords: Representation of the witch; Witch Craze; contemporary Paganism.

This article arose from the conference Misogyny: Witches and Wicked Bodies, which was held at the Institute of Contemporary Arts (ICA), London, in March 2015. My aim in organizing this event, which featured Alexandra Kokoli, Lynne Segal, and myself as speakers, was to consider feminist interpretations of the witch in contemporary

1. Katy Deepwell is professor of contemporary art, theory, and criticism at Middlesex University, London. She founded and edited n.paradoxa: international feminist art journal, 1998-2017. She is managing director of KT press. 
art and whether historical images of witches can be regarded as "woman-hating" or misogynist. Deanna Petherbridge, curator of the exhibition Witches and Wicked Bodies at the National Galleries of Scotland in Edinburgh in 2013 and in London at the British Museum in 2014-2015, was the keynote speaker. She focused on representations of witches in art, primarily by male artists in European art before the twentieth century, and identified elements of misogyny in these depictions of witches. These artworks routinely portrayed witches negatively as older women, crones and hags, particularly in fantasies about their sexuality, where they are depicted as voracious or repulsive, and often linked directly to Sabbath rituals as seen in, for example, Francisco Goya's graphic images of old women and witches in flight and burnt at the stake dating to between 1793 and 1823.

Here, I explore how the witch appears in three different feminist critiques of patriarchy, and subsequently pursue the ways in which these ideas have been taken up in contemporary art by women artists. The differences between three authors-Matilda Joslyn Gage (1893); Mary Daly (1984); and Silvia Federici (2004)-are contrasted to other historians' analyses from the last thirty years of the fate of women accused as witches during the European Witch Hunt between the fifteenth to eighteenth centuries. Historians remain unable to explain why women made up the majority of the accused and continue to refute the links between forms of violence against women in the witch-hunts and misogyny. Feminists, by contrast, see the witch-hunts in the context of patriarchal attitudes towards women in both the church and state in feudal Europe. These conflicts over interpretation inform the examples of contemporary art discussed here.

In theories of representation, images are often discussed as "reflecting" lived realities or as "depictions" of real events, but they are also presentations devised with imagination and fantasy which are not connected to the real. ${ }^{2}$ The Witch Craze or Witch Hunts in Europe across three centuries are generic terms for many real and different historical events, but the reasons for their occurrence and what the over-arching narrative means for the ways in which

2. John Berger, Ways of Seeing (London: BBC, 1972); Stuart Hall, ed. Representation: Cultural Representations and Signifying Practices (London: Sage, 1997); Jessica Evans and Stuart Hall, eds. Visual Culture: The Reader (Thousand Oaks, Calif.: Sage, 1999); Amelia Jones, ed. The Feminism and Visual Culture Reader (London: Routledge, 2003).

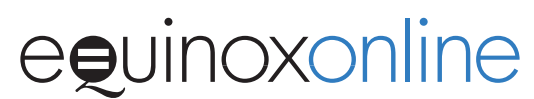


women-especially old women-are perceived and treated today is widely debated. From an artist's point of view, it is not simply that myths or stereotypes found in already existing representations of witches inform the images of women that they make, but how their own imagination, fantasy and story-telling extends or challenges the same myths or stereotypes and often transforms them. Images of the witch are very diverse in contemporary culture: there is no ideal type, but it is against common understandings and recurring representations linking women to witchcraft that the women artists, discussed here working with feminist ideas, provide different kinds of image-making.

Two examples of common and recurring images of witches from television and film draw on both historical narratives and fairytales. In both cases, the witches are seen from the perspectives of key characters (and audience) who arrive in another world, either by time-travel or flight. In the English science fiction time-traveling drama, Doctor Who (BBC 2018), the Doctor (in this series played by a woman) and her companions arrive in the seventeenth century at a village next to Pendle Hill in Lancashire, the site of the infamous trials of 1612 during which sixteen women were accused and ten were hanged for witchcraft. Three common understandings evident within the history of the Witch Hunts inform the show's narrative. First, that the women accused were generally poor, single and elderly, and often made simple remedies to cure their neighbors-in this episode a grandmother who is a local healer is killed by the dipping stool; second, the use of witch-finding manuals-depicted here as anti-Satanic codes of practice-including King James VI's Daemonologie (1597) (King James himself appears in the episode to aid the land-owner who leads the witch-hunt); and third, the use of new instruments devised to torture victims as part of a trial, such as the dipping stool. ${ }^{3}$ Doctor Who is science fiction rather than history, and in this episode a tree trunk which forms the dipping stool turns out to be the key to the plot: as when it was chopped down by the female landowner to improve her view of the landscape, its removal opened a doorway that allowed imprisoned alien beings from another galaxy, intent on absorbing humanity by the possession of human

3. These methods of witch swimming and "pricking" were used by Matthew Hopkins, known as the Witch-Finder General in England in the 1640s. See Malcolm Gaskill, Witchfinders: A Seventeenth Century English Tragedy, (Cambridge, Mass.: Harvard University Press, 2005).

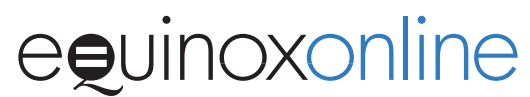


bodies in revenge for their long imprisonment, to invade and which the Doctor then had to fight.

In the well-known film, The Wizard of $\mathrm{Oz}$ (1939), the representation of witches rests on a fairy tale distinction between "good" and "bad" witches; Glinda, the Good Witch of the North, and the evil Witches of the East and West. This distinction is memorable because "good" and "bad" correspond to beautiful/good and ugly/wicked in the witches' appearance. This is made explicitly visual within this early Technicolor film; the wicked witch has green skin, a pointed nose and chin, and wears a black hat over her black hair, black flowing robes and holds a wooden staff. The good witch has blonde curly hair, red lips, wears a sparkling white ball-gown, and holds a magic wand. The protagonist, Dorothy, kills the two wicked witches of the East and West almost by accident, liberating the Land of $\mathrm{Oz}$ from their campaign of terror. Key characters in Dorothy's home world of rural 1930s Kansas correspond to some of those she meets in the surreal world of Oz. In particular, the Wicked Witch of the West is obviously based on her unpleasant spinster neighbor, Miss Gulch, and her threat to Toto, Dorothy's dog, forms the lynchpin of the entire story. There is, however, no corresponding home world character for Glinda, the Good Witch, who bestows upon Dorothy the deceased Witch of the East's ruby slippers that enable her to return home. The Wizard of $\mathrm{Oz}$ can be interpreted as a morality tale from worlds without feminism: without female friendship or support between women, only kin. The film rests on an interplay between two worlds, one "real" (rural Kansas) and the other "fiction", (Oz), but both stories are fantasies projected within the storyline of a film, which is neither documentary nor history.

Professor of English literature Diane Purkiss begins her book, The Witch in History (1996) by contrasting the two kinds of witch we have seen in the above examples: the innocent witch/healer living on the edge of the village and the evil witches in $\mathrm{Oz}$, both of which she would happily destroy. ${ }^{4}$ Purkiss rightly points to how the fantasy figure of the witch has served as an inspiration for many feminists, but polarizes her interpretation into either the "uncritical reproduction of an ideological femininity of selflessness" or the "bad" antihousewife who pollutes and disorders. ${ }^{5}$ Purkiss is particularly keen

4. Diane Purkiss, The Witch in History: Early Modern and Twentieth-Century Representations (London, Routledge, 1996), 8, 19, 47.

5. Ibid., 10. 
to challenge the image of the witch as it appears in the work of some contemporary radical feminist writers, such as Mary Daly, Andrea Dworkin, and Starhawk, who make links between "the Burning Times" or historic Witch Trials and 1970s feminist campaigns highlighting violence against women. In her analysis, she contrasts her own academic critique of witch representations as decidedly antiessentialist and properly historical, against those which she judges as transhistorical or pure fantasy. In a similar fashion, she contrasts two camps of interpreters for the Witch Hunt: on the one hand, radical feminists who highlight instances of oppressive persecution of women and, on the other, academic (male) historians who seek empirical evidence about witches while rarely exploring how gender operates within that evidence. ${ }^{6}$ Both sides of this equation are caricatures; however, this type of "myth-busting" of radical feminist claims is evident within many historians' analyses of the Witch Trial period. ${ }^{7}$

Feminists have invoked many more types of representations of witches for inspiration than Purkiss mentions, knowing full well that their dissenting words about the patriarchal status quo appear heretical. ${ }^{8}$ They have also identified with the women accused of and killed for witchcraft, and interpreted the Witch Trials as a war against women who do not conform to heteronormative or dominant society's expectations of women. ${ }^{9}$ Monica German argues that the appeal of the witch, especially in gothic and fantasy writing, is due to her "simultaneous embodiment of female marginalisation and feminist

6. Ibid., 11. See Ronald Hutton, "Review of The Witch in History: Early Modern and Twentieth-Century Representations," https://www.history.ac.uk/reviews Lreview/16.

7. Brian Pavlac, "Ten Common Errors and Myths about the Witch Hunts, Corrected and Commented." Prof. Pavlac's Witch Hunts Page. 9 August 2017. www .brianpavlac.org/witchhunts/werrors.html.

8. Heresies was the name of an American feminist art journal which also produced a goddess issue. Sorcieres was also the title of a French feminist journal. See Justyna Sempruch, Fantasies of Gender and the Witch in Feminist Theory and Literature (West Lafayette, Ind.: Purdue University Press, 2008).

9. Silvia Bovenschen, Jeannine Blackwell, Johanna Moore and Beth Weckmueller, "The Contemporary Witch, the Historical Witch and the Witch Myth: The Witch, Subject of the Appropriation of Nature and Object of the Domination of Nature," New German Critique, 15 (Autumn, 1978), 82-119. See also documentation of Ulrike Rosenbach, "Schule fur Kreativen Feminismus in Koln (1976-1982)," I, n.paradoxa: international feminist art journal 26 (July 2010), 66-9.

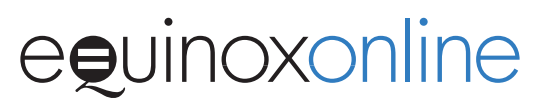


subversion."10 In 1968, W.I.T.C.H., a radical feminist group derived from a split in the New York Radical Women group, developed an inspirational feminist subversive protest, using the letters of their name as an acronym for "Women's International Terrorist Conspiracy from Hell." W.I.T.C.H. organized street actions and public protests that included placing a hex on Wall Street, and their activism has become a regularly reclaimed image for feminism today because its early protests, which extended from New York to Berkeley and Chicago, reversed a negative stereotype about women (as witches) for feminist ends. This approach to the figure of the witch is quite distinct from the feminist interpretations of matriarchal, Pagan, and pre-Christian religions, invoked as alternatives to oppressive forms of patriarchal Western capitalism, which Purkiss argues do not stand up to the evidential base provided by twentieth-century historical scholarship. Although many kinds of myths are regularly explored in feminist art, a more complex approach to the multiplicity of images of witches is needed. ${ }^{11}$

Amongst historians, there is still little consensus about the scale and scope, as well as the rationale, for accusations against witches. Gustav Roskoff's (1867) estimated account of nine million women killed in the Witch Craze, ${ }^{12}$ which was repeated by Matilda Joslyn Gage in 1893, has today been revised down to 35,000-100,000 deaths over a period of three hundred years, based on estimates from documented trials, but this number remains imprecise. ${ }^{13}$ Whether using empirical, political or anthropological explanations, historians do not agree on why trial records show such variation between countries, for example, four executions in Ireland compared with 26,000 in Germany; what determined the proportion of male or female witches accused in each case; or why distinct patterns of growth

10. Monica German, Scottish Women's Gothic and Fantastic Writing (Edinburgh University Press, 2010).

11. Historian Jeffrey Burton Russell makes important distinctions between three types of witch: "the sorcerer who practices the simple magic found worldwide; the heretic who allegedly practices diabolism and was prosecuted during the witch-craze; and the contemporary conscious revival of Paganism and magic." Jeffrey Burton Russell, A History of Witchcraft (London: Thames and Hudson, 1980, 2007), 172.

12. Julian Goodare, The European Witch-hunt (London: Routledge, 2016), 366.

13. Jenny Gibbons, "Recent Developments in the Study of The Great European Witch Hunt," The Pomegranate: A New Journal of Neopagan Thought 5 (Lammas 1998): 2-16. https://kersplebedeb.com/posts/gibbons_witch-2/. 
and contraction in the numbers of accusations occurred in different towns and regions over three hundred years. Brian Levack emphasizes that only forty-eight percent of 110,000 documented trials for witchcraft ended in the accused's death, and many, particularly in Britain, were hanged rather than burned, thus arguing that using the phrase "Burning Times" is inaccurate. ${ }^{14}$ The academic historical consensus is that across three centuries, seventy-five to eighty percent of those accused in recorded trials were women; however, the numbers accused across Europe varied widely in time and location. ${ }^{15}$

Historians do agree on how existent records of trials show the incredible variation between countries (for example, four executions in Ireland compared with 26,000 in Germany). Iceland executed primarily male witches; and men outnumbered women among those executed in Russia, the Baltic lands, Normandy, Finland, and Carinthia (in Austria); while in Germany around half of the male witches accused (twenty percent of the total number) were known to be relatives or partners of female witches. ${ }^{16}$ Elaine Breslaw's anthology of research on witches opens a more global or trans-Atlantic account of the emergence of witch trials at different times, while offering more detailed studies of accusations made in individual cities and regions. ${ }^{17}$ Although women, as well as men, did accuse other women of witchcraft, ${ }^{18}$ and men were also accused of witchcraft, it was men who were the torturers, the jurors, and the judges in these trials. While the Witch Trials have been called a "gender-cide" because they were a "gender-selective mass killing," the difficulty of grouping all witch-hunts, including those of Salem, Massachusetts, under this heading reduces the actual complexity of their causes and frequency in different parts of early modern Europe to

14. Brian Levack,The Witch-Hunt in Early Modern Europe (London: Routledge, 1987).

15. Peter T. Leeson and Jacob W Russ, 'Witch Trials', Economic Journal 128 (2018): 2066-2105. This statistical study does not discuss gender or women at all. Seventyfive percent of the 43,240 accused between 1300 and 1850 in 10,805 trials occurred in just five countries: Germany, Switzerland, France, England, and the Netherlands.

16. Levack, Witch-Hunt.

17. Elaine G. Breslaw, Witches of the Atlantic World: A Historical Reader and Primary Sourcebook (New York: New York University Press, 2000).

18. Robin Briggs, Witches \& Neighbours: the Social And Cultural Context of European Witchcraft (Penguin, 1988) 264-65. Robin Briggs concluded that amongst accusers, "It is really crucial to understand that misogyny in this sense was not reserved to men alone, but could be just as intense among women."

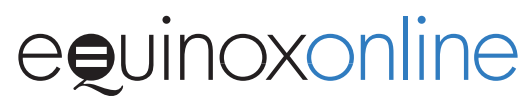


a one-dimensional argument. ${ }^{19}$ Other claims for "feminicide" -for example in the unsolved murders of women in the border towns of Juarez, between the United States and Mexico-encounter the same problems, especially in a climate of heightened civil violence. ${ }^{20}$

Published literature on the Witch Hunts has increased in recent years, as have variations in explanations around gender. ${ }^{21}$ Much of this work has focused on developing the evidence base from the recording of the trials. The execution of sixteen women and two men for witchcraft in a single day (27 August 1645) in Bury St Edmunds (a small English town), for example, still has the power to shock. ${ }^{22}$ The horrible reality of women being tortured into confessing to witchcraft as well as the stigma attached to the accusation itself remains, and is regularly invoked today in the use of the phrase "witch hunts," especially in business or politics, as a term for a process where an individual (male or female) is targeted, stigmatized and threatened. Wolfgang Behringer concludes that the "anxiety-ridden fantasies of witchcraft relates to their character as a construct" and this throws light on the dynamics of witch stereotypes about women as well as "the fragility of scientific hypotheses, and the danger of moral entrepreneurs in politics, science, law courts, at Universities and in the neighborhood." ${ }^{23}$ Mythical and fairy tale images of witches persist because they are effective constructs in this moral sense.

Brian A. Pavlac claims that the Witch Hunts cannot be regarded as a "feminicide" against women in a patriarchal society, even though the judges and authorities convicting and executing witches

19. See details of Essex Witch Trials, http://www.witchtrials.co.uk/ and Kirsten C. Uszkalo. "Throwing Bones," The Witches in Early Modern England Project, 2011. http://witching.org/throwing-bones/ .

20. For a feminist art project on this subject, see Jamie Ratliff, "A War on Women: Teresa Margolles' Cuidad Juarez," n.paradoxa: international feminist art journal 35 (January 2015), 56-65.

21. Lara Apps and Andrew Gow, Male Witches in Early Modern Europe (Manchester: Manchester University Press, 2003); Rolf Schulte, Man as Witch: Male Witches in Central Europe (Basingstoke: Palgrave Macmillan, 2009) which highlights several regions in Russia, Normandy, Germany, and Eastern Europe that were exceptions to this well-known pattern and highlights the differential gendering of specific accusations of witchcraft against men or women. See also Alison Rowlands, ed., Witchcraft and Masculinities in Early Modern Europe (Basingstoke: Palgrave Macmillan, 2009).

22. This trial was conducted by Matthew Hopkins: https://www.witchcraftan dwitches.com/trials_bury.html.

23. Wolfgang Behringer, Witches and Witch-hunts (Cambridge: Polity, 2004) 247. 
were exclusively men. In this he agrees with Levack's assessment that hunting women as witches was "a sex-related but not a sexspecific crime" 24 and Larner's careful assessment of it as "one degree removed" from an attack on women, whose aim was "enforcing moral and theological conformity." ${ }^{25}$ In contrast, Anne Barstow argues that the problem of violence against women today is linked to the Witch Hunts and insists that gender must be a factor in their analysis in order to explain why women were targeted. ${ }^{26}$

Historians recognize that the majority of accused women were believed to have been over fifty years of age and often widows or elderly women who were never married, their most distinguishing feature being that they were without family or male relatives to protect them, although some married women were also targeted. Women in feudal and early capitalist societies were regarded as "chattel," yet this attitude towards women as "property" owned by men, is rarely at the center of historians' analyses. Barbara Ehrenreich and Deirdre English in 1973 alternatively explained the Witch Hunts as the last stage in an attack on women healers by the new elite of universitytrained and male-only medical profession, arguing that it continued to have consequences into the present day in the dismissal of women's work as healers within nursing, midwifery and, in the twentieth century, as doctors. ${ }^{27}$ Historians have argued that healers, or "wise women", were a minority of the women accused and that the production of simples to cure common ailments was widespread as a practice in the community and did not represent a speciality, noting that accusations of witchcraft commonly arose where unexplained disease or sudden death occurred. ${ }^{28}$

Lyndal Roper examines the Witch Craze through a psychoanalytic lens in terms of the "fantasies which propelled it and the skewed

24. Levack, Witch-Hunt, 141.

25. Christina Larner, Enemies of God, The Witch-Hunt in Scotland (London: Chatto and Windus, 1981), 92, 102.

26. Anne Barstow, argues for three issues in relation to the trials: "the meaning of the gender of the victims...the excessive use of violence primarily inflicted by men against women and the sexual nature of much of that. Anne Barstow, Witchcraze: New History of the European Witch Hunts (San Francisco: Pandora/Harper Collins, 1994), 2.

27. Barbara Ehrenreich and Deirdre English, Witches, Midwives and Nurses (New York: Feminist Press, 2010 [1973]).

28. Levack, Witch-Hunt, 138 identifies women accused as "cooks, healers, and mid-wives." 
emotional exchanges it generated" in an age where control of fertility was paramount and threats to fertility in sexual reproduction as well as food production were ever present. ${ }^{29}$ Roper contrasts the literature on witches in Witch Hunt manuals/treatises with manifestations of the witch in the developing world of fiction and growing interest in the publication of old folk tales in the eighteenth and nineteenth centuries. Christian texts describing witches reinforce ideas about them as both good and evil, visible and hidden, by categorizing specific features of a witch's behavior, appearance, actions, and manners. Roper, however, clearly distinguishes this image of the witch in deliberate works of imagination from that of the witch within religious treatises and manuals designed to identify witches as associates of Satan, including works such as the Malleus Maleficarum (1487). She wants to show how these images created stereotypes and a specific narrative about witches which was largely fictional and highly anecdotal.

Representations formed as political or imaginative allegories within visual art often exist in contrast to either the "realities" of everyday life or any attempt to recount historical experiences, including those defining feminist analyses of patriarchy. Women artists have become interested in how feminism has thought about witches as a second order re-telling of historical experiences with feminist ends in mind. The threads of this relationship between the allegorical or typical images of witches, sirens, and hags, and real events, accusations, trials and executions are very hard to reconstruct. Wrenching them apart can be productive as a means to distinguish between what is known about the trials and belief systems of previous centuries and what is projection, myth, or fantasy. In the Witches and Wicked Bodies exhibition, the history of witch hunts across Europe were documented by a succinct timeline displayed on the gallery wall, but few women artists' works were included which would have provided a gendered comparison between artists' approaches.

Matilda Joslyn Gage in her book, Woman, Church and State (1893), was the first to propose a feminist and gendered analysis of the

29. Lyndal Roper Witch Craze: Terror and Fantasy in Baroque Germany (New Haven: Yale University Press, 2004) 6. Another study by Chris Hudson, "Witch Trials: Discontent in Early Modern Europe," uses a quantitative data analysis of the weather plotted against the witch-hunts location and density, arguing that dramatic changes in the seasons or temperature also contributed to the rise in accusations of witchcraft because crops failed and unexplained natural phenomena occurred. See http://repec.graduateinstitute.ch/pdfs/Working_papers/HEIDWP11-2016.pdf. 
persecution of women as witches, arguing that both the church and the state "collaborated against the female sex." Her text was written in the nineteenth century, when women had no voting rights, few rights to their own property, money or children, marriages were often arranged, rape in marriage was not recognized, women were unable to work in professions such as law, medicine or government, and few had access to university education. Alongside Susan B. Anthony and Elizabeth Cady Stanton, Gage was one of the political theorists of the liberal tradition, a founder of the American women's movement, and an anti-abolitionist activist. She is rarely cited in books on witch-hunts these days, although echoes of her arguments are often repeated in feminist texts such as the previously mentioned work by Ehrenreich and English.

Gage's work situates the figure of the witch within an examination of early matriarchies, marquette, ${ }^{30}$ celibacy, and polygamy in relation to marriage, and social expectations of wives and women's work. Her primary ambition is to demonstrate that the teachings of the church degraded women "by destroying her self-respect and teaching her to feel consciousness of guilt in the very fact of her existence." She examines hypocrisy within common superstitions as well as statements by her contemporaries (public figures from church and state) on women's education and knowledge, and reviews the extensive catalogue of literature regarding women's behavior in different centuries. Gage outlines three dominant traits used to identify a woman as a witch: firstly, the presence of "familiars" as indicative of the closeness of woman to animals as both are treated as chattel (to be bought and sold); secondly, the practices of "witch-pricking" as a means to search women's bodies for physical marks of evil including teats for animals or the devil to suckle; and thirdly, how within the teaching of the church younger women were regarded as for men's sensual use while older women after menopause were considered as having forfeited all right to life." ${ }^{\prime 1}$

Witches are only one part of Gage's argument about the way church and state codify social norms and recycle myths and folk superstitions to justify cruelty, torture, and victimization with the

30. Matilda Joslyn Gage, Woman, Church and State (Watertown, Mass.: Persephone Press, 1980 [1893]), 66-93. Marquette is the practice of young women serfs being considered or used as the rightful prey of the feudal lord for from one to three days after their marriage, and from this custom, the oldest son of the serf was held as son of the lord."

31. Gage. Woman, Church and State, 117.

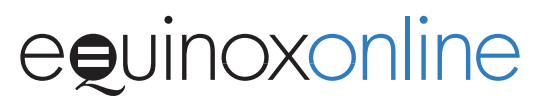


aim of undermining women's position in society and curtailing their opportunities in life, work and education. She suggests that "The three most distinguishing features of the history of witchcraft were its use for the enrichment of the church; for the advancement of political schemes; and for the gratification of private malice." ${ }^{\prime 32}$ As a result, "women of superior intelligence" involved in healing, medicine and anesthetics for childbirth were accused alongside the "insane, the bed-ridden, the idiotic" because both groups were regarded as threats to the new social order. Gage also discusses disputes between villagers, and the fact that other women were also accusers, but notes that it was men who brought female witches to trial. She examines the ways in which ideas motivate individuals and how the social order discriminates against women. In contrast to Purkiss' abovementioned account, Gage proposed that torture and physical punishment used against women accused of witchcraft acted as a social warning and deterrent to other women gathering to express dissent or collectively organize. The fear of accusation became a threat to women expressing dissent or taking political action. Gage's feminist thesis is that women should not see self-sacrifice as their duty or destiny because this compounds the problem of "the protective spirit (of men) [that] does injury to women" and keeps women in a state of dependency, bondage or slavery. Instead she argues women should pursue "self-development" through education. ${ }^{33}$

Mary Daly builds on Gage's critique, and actively promoted it by republishing this feminist foremother's work in 1980. Daly aimed to develop a cosmology whereby the very negative attributions of women in church theology are inverted into positives and selfdevelopment is promoted. Her "Elemental Race of Wild and Lusty" women in Pure Lust (1984) envisages a process of self-discovery and free thinking as a journey to enlightenment, passing through three spheres or stages: "Archespheres, Pyrospheres, Metamorphospheres." This journey of discovery and redemption re-writes religious sources and ideas regarding pilgrimages or journeys of self-transformation. Daly aims to use "radiant words" to name elemental sources for sisters, muses, friends and selves as "Gnomes, Undines, Salamanders and Sylphs." Her cast of characters, "Weirds, Websters, Wantons, Scolds, Shrews, Sprites, Dikes, Viragos and Prudes" attack the "snools of the sado-state (agents of atrocities,

32. Ibid., 106.

33. Gage, Woman, Church and State, 240. 
fixers, Drones and Chairmen of the Bored) and importantly befriend, be-long and be-witch other women of like minds in Gyn/ Affection." ${ }^{34}$ In one passage, Daly describes how snools, plug-uglies, and prickers have instituted a new cockocracy/jockocracy against women, mirroring the witch-hunt. ${ }^{35}$ Daly's text was written during the Reagan years, which saw a backlash against professional women, even as the numbers of women in management roles continued to increase. ${ }^{36}$ Purkiss' critique of Daly's radical feminism is centered on refuting the manner in which the past is used to speak to present realities, because doing so collapses historical distance between eras and cultures that had quite different belief systems. I argue, however, that such a stance misses the point: Daly is not interested in historical realities, but metaphors and narratives. Instead, reinvention and re-imagining take priority. Unlike her other books, in Pure Lust, Daly is building an alternative fiction of radical feminist enlightenment based on self-development-rather than self-sacrifice or domesticity-and suggesting alternative cosmologies for women to those offered by the established church.

Silvia Federici's historical account of the Witch Trials offers an important link between accusations against women and an increase in the violence against women at specific stages of primitive accumulation, ${ }^{37}$ not only during the emergence of capitalism in early modern Europe, but within colonialism and today amidst globalization. Federici's witch combines "the heretic, the healer, the disobedient wife, the woman who dared to live alone, [with] the 'obeha' woman who poisons the master's food and inspired the slaves to revolt." ${ }^{\prime 38}$ This is a third and different characterization of the witch from either Gage's or Daly's approaches. Federici focuses on accused women that include peasants/subsistence farmers, midwives, heretics, and Beguines, as well as independent skilled craftswomen in cities alongside beggars, the homeless, the poor and those driven to prostitution. Many of these

34. Mary Daly, Pure Lust (London: Women's Press, 1984), 21. This text is closely related to her two other books Beyond God the Father (1973) and Gyn/Ecology (1978).

35. Ibid., 23-4

36. Susan Faludi's Backlash: The Undeclared War Against American Women (New York: Doubleday, 1991) is a later treatment of the same idea.

37. Primitive accumulation is the process by which pre-capitalist modes of production, such as feudalism and chattel slavery, are transformed into the capitalist mode of production.

38. Silvia Federici, Caliban and the Witch: Women, the Body and Primitive Accumulation (New York: Autonomedia, 2004). 
women, because of the economic changes, if old or single women, were dependent on barter/exchange for survival. Both early capitalism and colonialism produced mass pauperization in the population of Europe and the colonies. This is how Silvia Federici identifies the Witch Craze as a "transition fiction" in the period 1450-1650 as Europe moved from feudalism to capitalist forms re-organizing the economy and labor (serfs become wage laborers without land), as well as developing colonies (and slavery). This is why she links in the figure of Caliban as the anti-colonial rebel to the witch, as both are scapegoats and rebels in early capitalism's pursuit of its territorial claims, via enclosure or land expropriation and its degradation of women and other races outside Europe. Persecution was a means of social control and mass psychosis. ${ }^{39}$ Property seizure is linked in her analysis to the loss of a commons-any shared and communal use of the land and resources evident in barter economies-and she identifies this process as linked to the introduction of wage labor and dependence on money. The price of food, especially when subsistence farming crops failed to supply basic needs and wage work cannot be found, is central to the argument. ${ }^{40}$ Another feature of this transition to capitalism and colonial rule, she argues, is marked by significant rises in violence to women and this is why they are evident again today in the process of globalization around the world. ${ }^{41}$

Federici's account draws on Maria Mies' 1986 work, Patriarchy and Accumulation on a World Scale, which presented a critique of the ways rationality and progress have been used by modernizing imperializing societies to justify the exploitation of labor, as well as nature, through violence and accumulation of profit. ${ }^{42}$ Federici's account critiques both Marxist and Foucauldian analyses of the transition from feudalism to capitalism, and offers instead a gendered analysis that interprets the position of women in society as central rather than peripheral or additive. According to Federici, in the transition from a feudal economy to early forms of capitalism, witches were women who did not benefit from the resulting changes to the economy but were both impoverished and excluded from it and this was compounded by the accusation of witchcraft. Federici's account

39. Ibid., 167

40. Ibid., $76-77$

41. Ibid., 13-15.

42. Maria Mies, Patriarchy and Accumulation on a World Scale: Women in the International Division of Labour (London: Zed Books, 2014 [1986]). 
explains why different features of women's work have been attributed to the increased likelihood of their being accused of poisoning people (because they were intimately associated with food storage and preparation); of having a special relationship to cats and farmyard animals as familiars (because they had to look after them on farms); of crops failing (women were primarily agricultural laborers); of unexpected deaths, especially of children (they were also nurses, midwives or assistants at births, or were employed as wet-nurses and servants in wealthier households).

Federici offers a broad economic context in her theory of a "transition fiction" in early capitalism and colonialism. Her view extends the historical argument in gendered terms about why certain women were targeted (as evidenced by their dominance in the trials), namely, the impoverished widow over forty who fights with her neighbors. She gave food which made people ill and "simples"-everyday medicine, which not only did no good but poisoned. Her presence, when nursing infants or the sick, polluted or defiled. She overstepped her authority in other women's households for which they blamed her. She was not favored in local networks of friendship or bartering economies and was ostracized by others. When accused or placed under torture she confessed to her crimes and implicated others in her circle. Federici also argues that the history of witch hunts could not be explained only from the perspective of the witch-hunters: "Feminists were quick to recognize that hundreds of thousands of women could not have been massacred and subjected to the cruelest tortures unless they posed a challenge to the power, structure."13 This is why feminist explanations of the Witch Craze require attention to how these women lived and worked in economic and social terms, as well as to the gap between fiction and reality. In this complex history, witches are not just a metaphor or a construct about certain "bad" or "dissenting" women, but part of a story about capitalism and colonialism, and draconian measures to control women's lives.

\section{Documenting the Witch-Craze}

The second part of this article presents nine works by contemporary women artists in order to demonstrate how the problems raised above about the history and interpretations of the Witch Trials and

43. Federici, Caliban and the Witch, 168.

(C) Equinox Publishing Ltd 2020

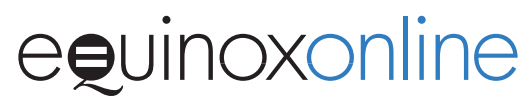


the associations of women as witches provide different kinds of feminist narratives. The artworks have been tentatively grouped into three themes: (1) documenting the witch-craze; (2) Contemporary Paganism/Goddess worship; and (3) women's association in witchcraft with animals as familiars.

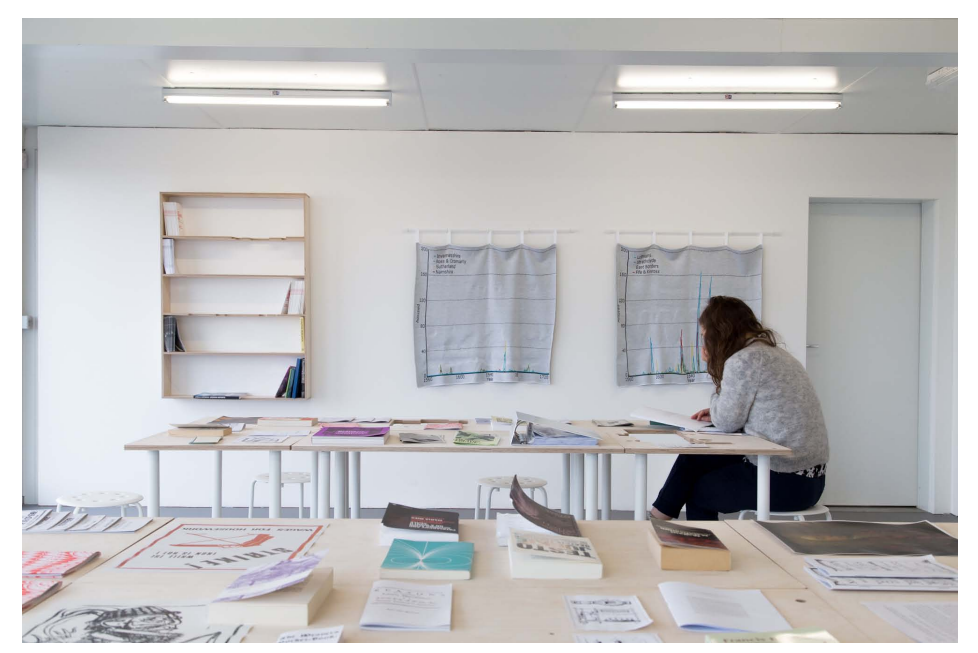

Figure 1: Georgia Horgan, Machine Room (Collective Gallery, 2015) installation view. Photo: Tom Nolan. Courtesy of artist.

In her 2015 installation/exhibition, Machine Room, ${ }^{44}$ artist Georgia Horgan re-examines the way in which the expansion of the textile industry in Scotland in the seventeenth century influenced patterns of witch-hunting (Fig. 1). In this assemblage, consisting of a temporary archive of diverse sources, Horgan presents books, papers, and images on the topic, including Christina Larner's book, Enemies of God: The Witch Hunt in Scotland (1981). These are laid out on a table and bookcase alongside the artist's production of specially woven tapestries that depict graphs showing the extent of the witchhunts in Scotland. The exhibition was accompanied by screenings of Ursula Biemann's video Performing the Border on the disappeared women of Juarez, Mexico, and Petra Bauer's Sister!, as well as a program of artist talks. ${ }^{45}$ The work is part reading room and museum-

44. Georgia Horgan, Machine Room, Collective Gallery: Edinburgh, FebruaryApril 2015.

45. Artist's website, Georgia Horgan, http://georgiahorgan.co.uk 
type display, the exhibit having been designed to raise awareness and inspire public conversation on the nature of the witch-hunts. Presenting "objective" evidence in this way, Horgan highlighted the multiplicity of viewpoints on these events about which the gallery audience may have had only partial or anecdotal knowledge. This work was succeeded by further explorations of women, textiles, and labor by the artist as, for example, the 2017 video, All Whores are Jacobites, more directly influenced by Silvia Federici's work.

In Ann-Sofi Sidén's work CODEX: from the city stones to the seat of shame: a reconstruction (1993) the artist presented eleven criminal cases of witchcraft in Swedish court records from 1475 to 1833, which culminated in public sentences against women. This artwork examines the confessions extracted from women under torture, including accusations of witchcraft, by re-enacting the extreme and physical character of the violence against them. The artwork was presented first as a three-channel video work in which the artist asked different women dressed in period costumes to re-enact the suffering produced by different instruments of torture. In the video the sounds were coupled with different narratives from trials and with voices describing the tortures inflicted. In a later work made in 2005, black-and-white photographs of the participants in the original video were juxtaposed with text panels that featured the instruments of torture, for example, stones hung around the neck on chains or the "Spanish Violin" (where the hands and neck were bound in stocks of wood). This work conveyed the horror of the accusation of witchcraft and the torture inflicted on women, as well as the rationale offered in the trial by the accuser and the defense offered by the accused in each case.

Ann-Christine Woehrl's photographic series "Witches in Exile,"46 in contrast to actual depiction of torture, presents positive and sympathetic portraits of women from the Ghanian regions of Gambaga (2009) and Gushiegu (January 2013) who have been exiled from their home villages because of accusations of witchcraft. Accusations against women as witches continue in different regions of the world and the reasons for them echo those of the European Witch Hunt, especially as defined by Federici. These Ghanian women are often past child-bearing age, own property or land which someone else wants, and have no one to defend them when witchcraft accusations

/machineroom/

46. Witches in Exile, exhibition at Berlin, Pinter \& Milch Gallery, April 2013. 
begin so are forced to flee and live in exile in villages with other women who have been similarly treated.

\section{Contemporary Paganism and Goddess Worship}

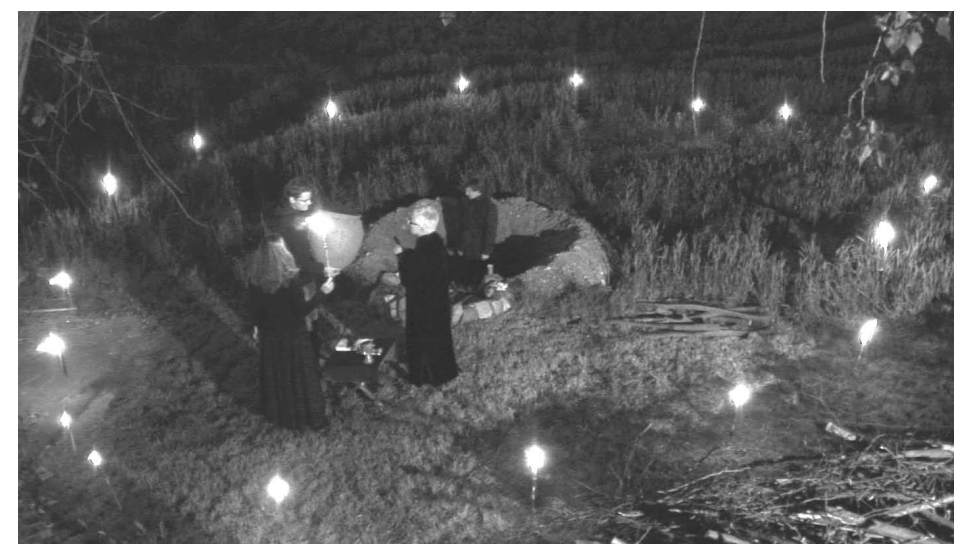

Figure 2: Mathilde ter Heijne, Experimental Archeology: Moon Rituals HD, single screen video (2007) Production shot, November 2006.

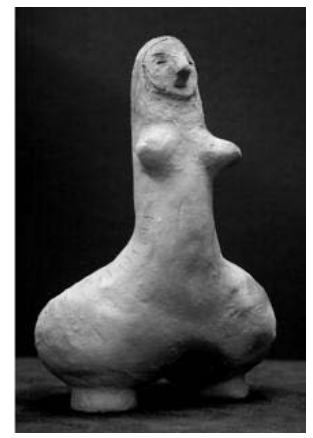

Figure 3: Mathilde ter Heijne, Female with Phallus Head Starcevo (Endröd-Szujóskereszt, Körös Valley, SE Hungary; c. 5600-5300 BCE). Fusion of Goddess power (buttocks, v-shaped incisions) and cosmic pillar (phallus form). Reconstruction of the original, wood-fired ceramic, $18.5 \times 13 \times 8 \mathrm{~cm}$. Photos: Kai Dieterich. Courtesy of artist.

Archaeologist Marija Gimbutas' works The Goddesses and Gods of Old Europe: Myths and Cults (1982) and The Language of the Goddess: Unearthing the Hidden Symbols of Western Civilization (New York, 1989), have been extremely influential in regard to feminist 
re-examinations of goddess mythologies in Old/Neolithic Europe (ca. 5000-2,500 вСE). Intrigued and inspired by Gimbutas' work, contemporary artist Mathilde ter Heijne created Moon Rituals (2006) as part of a series titled Experimental Archaeology: Goddess Worship (Fig. 2). The work was presented as a video installation which was combined with display of consecrated fertility objects that were re-creations of goddess images described and drawn in Gimbutas' archaeological publications (Fig. 3). In the video the artist and two Goddessworshippers fire and consecrate the objects at night under the moon. The ritual was concerned with testing the gap between contemporary art objects and sacred objects now preserved in archaeological museums, and was also an experiment to re-invest and question the potential investments in past matriarchal cultures.

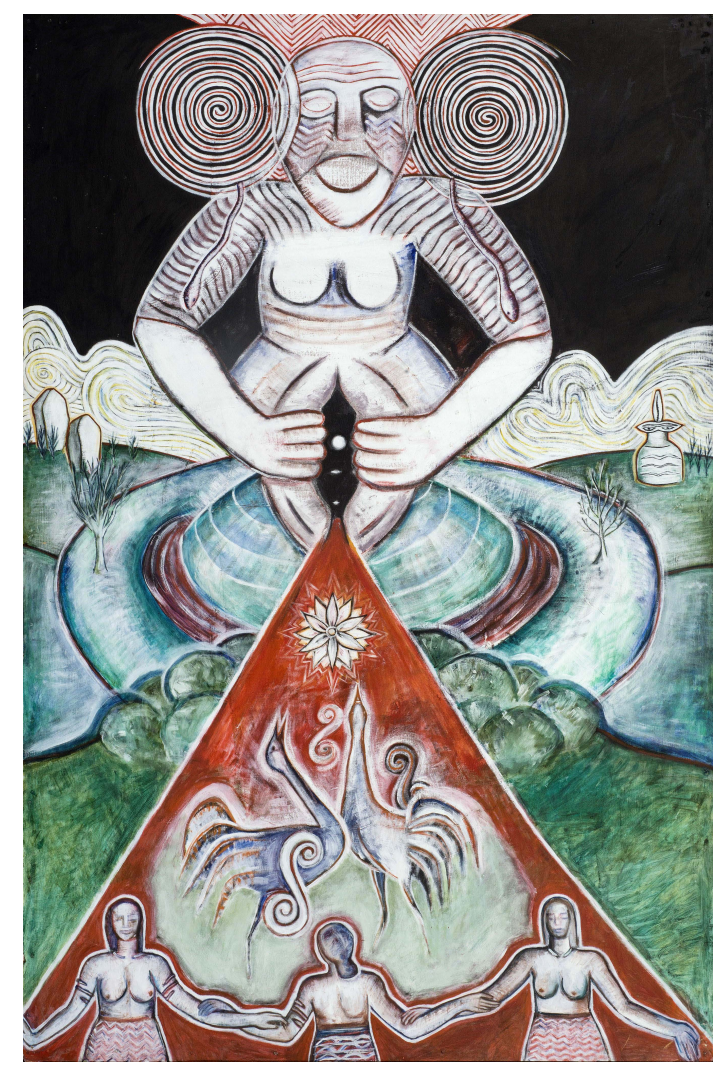

Figure 4: Monica Sjöö, Skapelsen Sheela na gig / Sheela Na Gig Creation (oil on hardboard, 1978) Courtesy of Museum Anna Nordlander, Sweden. 
Another well-known feminist painter, Monica Sjöö (who died in 2005), extensively explored ancient Pagan matriarchal cultures and offered a revived feminist spirituality in many of her works, as well as in her 1987 book co-authored with Barbara Mor, The Great Cosmic Mother). ${ }^{47}$ A well-known early painting by Sjöö, God giving Birth (1968), depicts a female figure giving birth to the world as an image of female empowerment and fertility. Sjöö's later works juxtaposed female bodies to elements within the Welsh landscape, combining Celtic and Norse myths that merged earth and fertility, as well as sacred stone such as dolmens and Stonehenge, and including Sheela-na-gig figures (Fig. 4). These paintings invoke Pagan beliefs in the earth as sacred and the interest in fertility and seasonal rituals involving cycles of the moon and sun. They do not celebrate or try to revive images of the witch, but explore strong female, potentially matriarchal, figures from many religions, and images of the power of women's fertility.

In Jesse Jones's video and installation work, Tremble Tremble, featured in the Irish Pavilion at the 2017 Venice Biennale, the artist created a giantess as an alternative giant/goddess/ancient witch who, among other gestures and speech, mouths the words of the Malleus Maleficarum backwards. This large ancient-looking figure, swathed in peasant clothes and with long white hair (played by actress Olwen Fouéré) appears menacingly on several large screens, reaching the full height of the exhibition space, in a pitch-black installation. Large prints of the figure's hands embrace the space when the invigilators move the voile curtains on which they are photo-screened around the space. Inspired by both Federici's Caliban and the Witch and the Wages for Housework movement who shouted "Tremble, Tremble" on their marches, this piece invokes the witch as a disruptive agent and aims to produce a "bewitching" feminist protest about women's labour and rights. Through this archetypal image the artist aims to uncover or suggest an archaic law of mythic proportions, Utera Gigantae, ${ }^{48}$ which would undercut and rewrite the current legal

47. See Monica Sjoo and Barbara Mor, The Great Cosmic Mother: Rediscovering The Religion Of The Earth (San Francisco: Harper, 1987), also Shai Feraro, “'God Giving Birth': Connecting British Wicca with Radical Feminism and Goddess Spirituality during the 1970s-1980s: A Case Study of Monica Sjöö," The Pomegranate: The International Journal of Pagan Studies 15: 1-2 (2013): 31-60; and Rupert White Monica Sjoo: Life and Letters 1958-2005. London: Antenna Publications, 2018.

48. Lisa Birch “Venice Biennale 2017 // 'Tremble Tremble' at the Irish Pavilion: An Interview with Jesse Jones." Berlin Art Link, 8 March 2017. http://www 
system and its limited rights for women in Ireland, as well as collusion between religious doctrine of the Catholic church and legal frameworks of the state (which until the 1990s refused to recognize rape in marriage and forbade abortion until December 2018).

\section{Familiars}

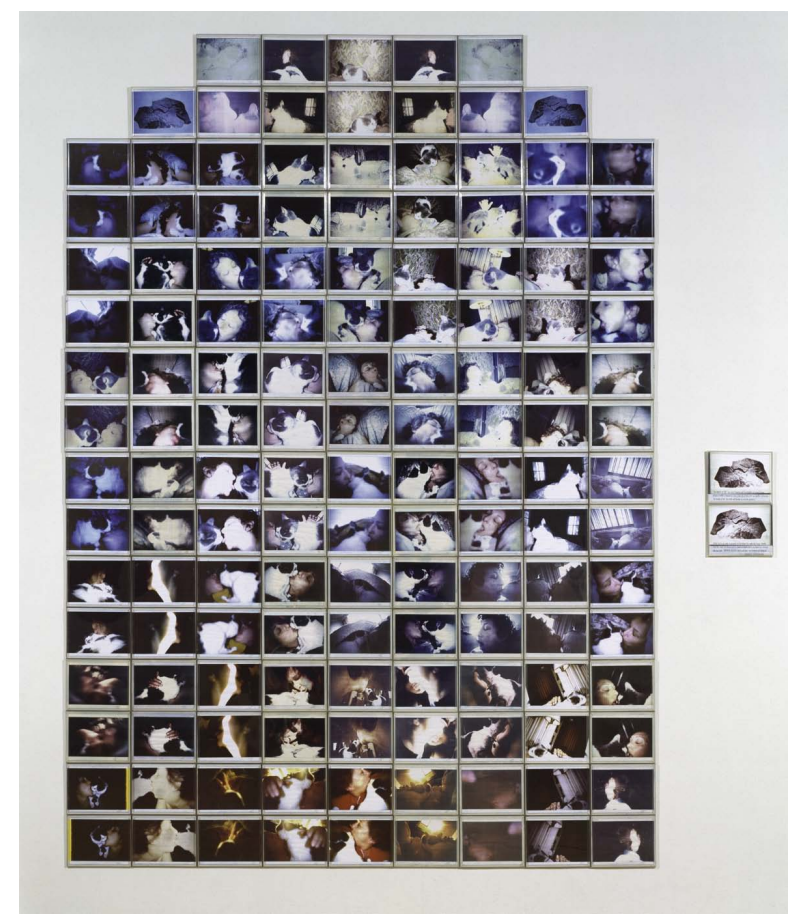

Figure 5: Carolee Schneemann, Infinity Kisses (Xerox ink on linen, 84 x 72 in. (213.36 x 182.88 cm), 1981-1987). San Francisco Museum of Modern Art, Accessions Committee Fund purchase: gift of Collectors' Forum, Christine and Pierre Lamond, Modern Art Council, and Norah and Norman Stone (c) Carolee Schneemann / Artists Rights Society (ARS), New York/DACs Society, London. Photo: Ben Blackwell.

In the video Vesper's Stampede To My Holy Mouth (1992), filmed and edited by Victoria Vesna and Carolee Schneemann, the artists set out to explore "suppressed feminist issues of female subjugation, the unconscious, the paranormal and goddess religions." The result

.berlinartlink.com/2017/03/08/venice-biennale-2017-tremble-tremble-at-the-irish -pavilion-an-interview-with-jesse-jones/. 
of two years of research and discussion, Vesna's portrait captures Schneemann's most intimate issues in her studio and home. Central to this video is Schneeman's essay, "Vesper's Stampede to My Holy Mouth," in which she interweaves three themes: "the erotic affections of her pet cat; female genital mutilation; and cat/clitoral condemnation at issue during witchcraft trials." ${ }^{49}$ While Schneemann has written many times about "ten generations of women" killed as witches and also extensively researched and used images of Cretan and Etruscan sculptures, the only imagery that could actually be connected with witches she used is her beloved cats, since her larger project was the exploration of female sexuality. The work is closely related to others that record Schneeman's cats kissing her, as seen in Infinity Kisses (1981-1987), which records eroticism and affection between animal and woman, juxtaposed with fragments of ancient pottery (Fig. 5). ${ }^{50}$

In a large installation, Of Mutability (1986), shown at the ICA, London, artist Helen Chadwick created a tableau of repeated images of her own naked body in a baroque burlesque with animals and fruit. The images are printed in white/grey/silver on a large blue table of panels where images are collaged together, circling one another. The imagery of animals, fruit, flowers and a nude woman was highly sexual and sensual, mirroring imagery from Baroque painting. Several golden balls sit on the panels-globes, orbs or weights, like the scales of justice. On the other side of the installation was a glass cylinder filled with fruit and vegetables, designed to rot slowly during the exhibition as a memento mori about life and death, fullness and decay (unfortunately it cracked or exploded during the exhibition and was removed). The work was a mythic invocation of the association of women and animals, sexuality and fertility drawing on imagery from the seventeenth century.

In her photo-series, Tania Antoshina employed the remarkablelooking white-haired eighty-year-old model, Pani Bronia, to create Europe: Queen of the Night (1999). Handsome, naked young men sit enraptured by the story told by this naked woman. Reversing roles has been a trait in Antoshina's earlier works, such as Museum of A

49. Videopool, http://www.videopool.org/catalogue/titles/?isbn=1552607275.

50. See Vesper's Pool (video installation, 1999-2000) and Infinity Kisses (1981-1987, San Francisco Museum of Modern Art in Carolee Schneemann, Imaging her Erotics: Essays, Interviews, Projects (Cambridge, Mass.: MIT Press, 2002); and Kristine Stiles, ed., Correspondence Course: An Epistolary History of Carolee Schneemann and her Circle (Durham, N.C.: Duke University Press, 2010). 


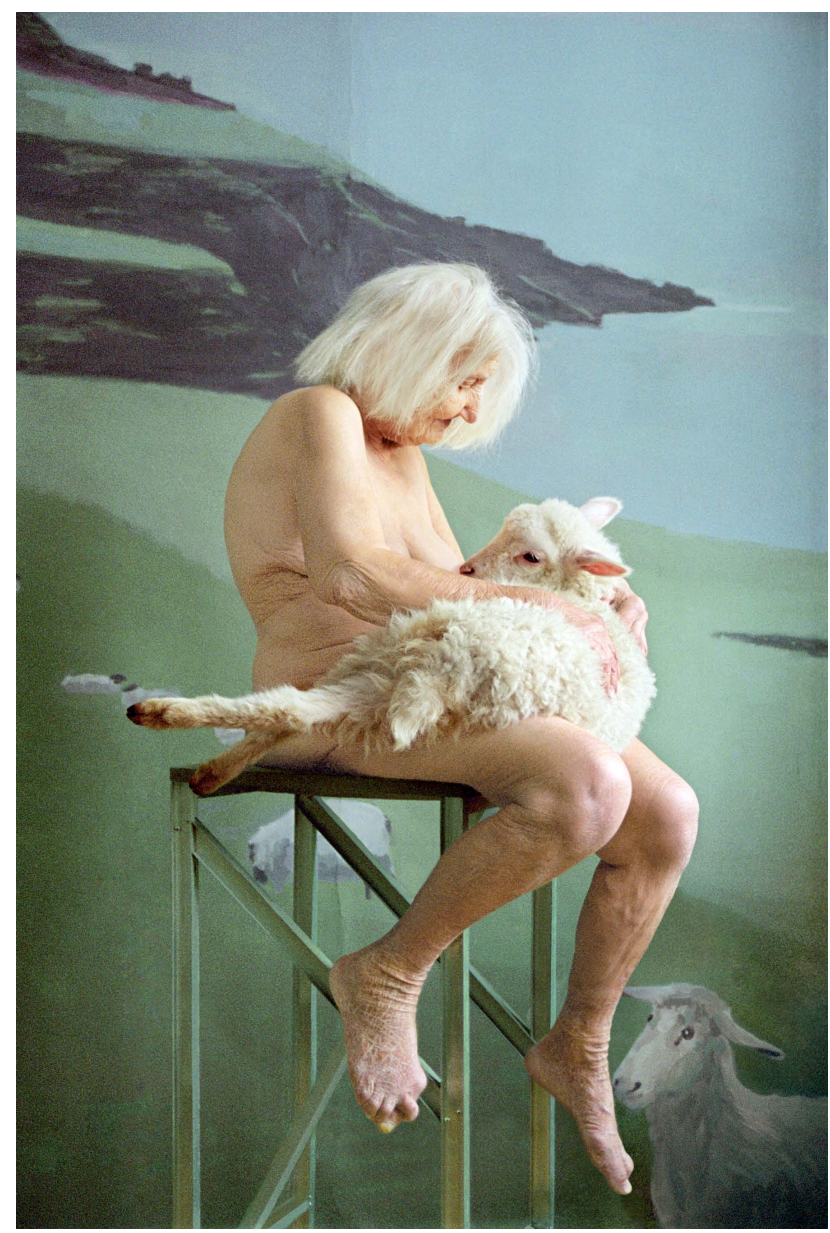

Figure 6: Tania Antoshina, Dolly (2004) from Europe series. color photograph. Courtesy of artist.

Woman, and Europe: Queen of the Night reverses the ever-popular media image of the older man surrounded by nubile young women, so central to Russian business and capitalism, by turning it into an allegory of modern times-especially given the rise of older women in business, professions and politics. In another work, Dolly (2004), the model holds a sheep as if nursing or suckling it (Fig. 6). This work references genetic advances in cloning animals as much as it makes explicit the old woman as a "nightmare" of modern medicine, still able to breastfeed and bear children beyond her child-bearing 
years, and as the embodiment of much older fantasies of the witches' mark as a teat for feeding the devil or animals. Both photo-works still have the power to shock and are presented as allegories of modern life, using neo-classical imagery in colour photography. By reversing expectations and roles they offer representations of older women as sexually active subjects that disturb the status quo.

\section{Conclusion}

These examples show how feminist writers on the Witch Craze and the witch continue to inform women artists' works even as each artist chooses to address events, fantasies, stereotypes, and alternative fictions about women in interesting and unexpected ways. None of these works show either "innocent" or "evil" witches, but equally they have not forgotten how the Witch Hunts figure in feminist thought. These works instead show how the witch remains a problematic figure for representing women's sexuality or the problem of violence against women especially when mixed with feminist ambitions for exposing patriarchal thought. None of the works could be said to endorse the witch as "nag" or "hag" or as a figure for reclamation, ${ }^{51}$ especially given the diversity of historical understandings about the Witch Hunt in circulation today. Instead these artists deliberately problematize the history, myths, and fictions that continue to associate women with witches in order to conceive and reimagine different models for feminist resistance.

\section{Bibliography}

Apps, Lara, and Andrew Gow. Male Witches in Early Modern Europe. Manchester: Manchester University Press, 2013.

Barstow, Anne. Witchcraze: New History of the European Witch Hunts. San Francisco: Pandora/Harper Collins, 1994. https://doi.org/10.2307/3039390.

Behringer, Wolfgang. Witches and Witch-hunts: A Global History. Cambridge: Polity, 2004.

Berger, John. Ways of Seeing. London: BBC, 1972.

Birch, Lisa. "Venice Biennale 2017. ‘Tremble Tremble' at the Irish Pavilion: An Interview with Jesse Jones." Berlin Art Link, 8 March 2017. http://www.berlinartl ink.com/2017/03/08/venice-biennale-2017-tremble-tremble-at-the-irish-pavil ion-an-interview-with-jesse-jones/. https://doi.org/10.1093/gmo/97815615926 30.article.53576.

51. Cynthia Eller, The Myth of Matriarchal Prehistory: Why an Invented Past Won't Give Women a Future, (Boston: Beacon Press, 2000). 
Breslaw, Elaine G. Witches of the Atlantic World: A Historical Reader and Primary Sourcebook. New York: New York University Press, 2000.

Briggs, Robin Witches \& Neighbours: the Social And Cultural Context of European Witchcraft. Penguin, 1988.

Bovenschen, Silvia, and Jeannine Blackwell, Johanna Moore, and Beth Weckmueller. "The Contemporary Witch, the Historical Witch and the Witch Myth: The Witch, Subject of the Appropriation of Nature and Object of the Domination of Nature." New German Critique 15 (Autumn,1978): 82-119. https://doi.org 10.2307/487908.

Daly, Mary. Pure Lust: Elemental Feminist Philosophy. London: Women's Press, 1984.

Deacon, Richard. Matthew Hopkins; Witch Finder General. London, Frederick Muller, 1976.

Ehrenreich, Barbara, and Deirdre English. Witches, Midwives and Nurse. New York: Feminist Press, 2010 [1973].

Eller, Cynthia, The Myth of Matriarchal Prehistory: Why an Invented Past Won't Give Women a Future. Boston: Beacon Press, 2000.

Essex Witch Trials. http://www.witchtrials.co.uk/.

Evans, Jessica, and Stuart Hall, eds. Visual Culture: The Reader. Thousand Oaks, Calif.: Sage, 1999;

Feraro, Shai “'God Giving Birth': Connecting British Wicca with Radical Feminism and Goddess Spirituality during the 1970s-1980s: A Case Study of Monica Sjöö." The Pomegranate: The International Journal of Pagan Studies 15: 1-2 (2013): 31-60. https://doi.org/10.1558/pome.v15i1-2.31.

Federici, Silvia. Caliban and the Witch: Women, the Body and Primitive Accumulation. New York: Autonomedia, 2004.

Gage, Matilda Joslyn, Woman, Church and State. Watertown, Mass.: Persephone Press, 1980 [1893].

Gaskill, Malcolm. Witchfinders: A Seventeenth Century English Tragedy. Cambridge, Mass.: Harvard University Press, 2005.

German, Monica. Scottish Women's Gothic and Fantastic Writing. Edinburgh: Edinburgh University Press, 2010.

Gibbons, Jenny. "Recent Developments in the Study of The Great European Witch Hunt." The Pomegranate: A New Journal of Neopagan Thought 5 (Lammas 1998): 2-16. https://kersplebedeb.com/posts/gibbons_witch-2/. http://doi.org/10.15 58/pome.v13i5.2.

Goodare, Julian, The European Witch-hunt. London: Routledge, 2016.

Hall, Stuart, ed. Representation: Cultural Representations and Signifying Practices. London: Sage, 1997.

Hudson, Chris. "Witch Trials: Discontent in Early Modern Europe." http://repec .graduateinstitute.ch/pdfs/Working_papers/HEIDWP11-2016.pdf .

Hutton, Ronald. "Review of Diane Purkiss: The Witch in History: Early Modern and Twentieth-Century Representations." History 16. https://www.history.ac.uk /reviews/review/16. https://doi.org/10.4324/9780203359723.

Jones, Amelia, ed. The Feminism and Visual Culture Reader. London: Routledge, 2003.

Larner, Christina, Enemies of God, The Witch-hunt in Scotland. London: Chatto and Windus, 1981.

Leeson, Peter T. “Witch Hunts in the Western World, Past and Present." 1 September 2018. https://voxeu.org/article/witch-hunts-western-world-past-and-present. 
Leeson, Peter T., and Jacob W. Russ. “Witch Trials.” Economic Journal 128, no. 613 (2018): 2066-2105. https://doi.org/10.1111/ecoj.12498.

Levack, Brian. The Witch-Hunt in Early Modern Europe . London: Routledge, 1987.

Mies, Maria. Patriarchy and Accumulation on a World Scale: Women in the International Division of Labour. London: Zed Books, 2014 [1986].

Pavlac, Brian. "Ten Common Errors and Myths about the Witch Hunts, Corrected and Commented." Prof. Pavlac's Witch Hunts Page. 9 August 2017. www .brianpavlac.org/witchhunts/werrors.html

Petherbridge, Deanna. Witches and Wicked Bodies. Exhibition catalogue. Edinburgh: National Galleries of Scotland, 2013.

Purkiss, Diane. The Witch in History: Early Modern and Twentieth-Century Representations. London: Routledge, 1996.

Ratliff, Jamie. "A War on Women: Teresa Margolles' Cuidad Juarez." n.paradoxa: international feminist art journal 35 (January 2015): 56-65.

Roper, Lyndal Witch Craze: Terror and Fantasy in Baroque Germany. New Haven: Yale University Press, 2004.

Rosenbach, Ulrike. "Schule fur Kreativen Feminismus in Koln (1976-1982)." n.paradoxa: international feminist art journal 26 (July 2010): 66-69.

Rowlands, Alison, ed. Witchcraft and Masculinities in Early Modern Europe. Basingstoke: Palgrave Macmillan, 2009.

Russell, Jeffrey Burton. A History of Witchcraft. London: Thames and Hudson, 2007 [1980].

Schneemann, Carolee. Imaging her Erotics: Essays, Interviews, Projects. Cambridge, Mass.: MIT Press, 2002.

Schulte, Rolf. Man as Witch: Male Witches in Central Europe. Basingstoke: Palgrave Macmillan, 2009.

Sempruch, Justyna. Fantasies of Gender and the Witch in Feminist Theory and Literature Indiana, West Lafayette, Ind.: Purdue University Press, 2008.

Stiles, Kristine, ed. Correspondence Course: An Epistolary History of Carolee Schneemann and her Circle. Durham, N.C.: Duke University Press, 2010. https:// doi.org/10.1215/9780822391005.

Sjoo, Monica, and Barbara Mor. The Great Cosmic Mother: Rediscovering The Religion of the Earth. San Francisco: Harper and Row, 1987.

Uszkalo, Kirsten C. "Throwing Bones." The Witches in Early Modern England Project. 2011. http://witching.org/throwingbones/.

White, Rupert. Monica Sjoo: Life and Letters 1958-2005. London: Antenna Publications, 2018. 